\title{
Casamento, maternidade e viuvez: memórias de mulheres hansenianas
}

Marriage, maternity and widowhood: memoirs of leper women

Viviane Trindade Borges*

\section{RESUMO}

Neste artigo pretendo analisar as falas de quatro mulheres hansenianas, pacientes-moradoras do Hospital Colônia Itapuã, em Viamão (RS), observando a maneira como elas constroem determinada imagem de si mesmas. Num primeiro momento objetivo situar o leitor a respeito da instituição e da construção de tais entrevistas. Após, busco analisar as memórias femininas que povoam este estudo através de três posições de sujeito por elas ocupadas dentro da instituição, as quais se repetem em suas falas: 0 casamento, a maternidade e a viuvez. Procuro perceber as imagens construídas através de tais discursos, analisando a versão de si que tais senhoras desejaram imprimir.

Palavras-chave: hanseníase; memória; subjetivação.

\section{ABSTRACT}

In this article, my intention is to analyze the talk of four leper women, in-patients of the Hospital Colônia Itapuã, in Viamão, State of Rio Grande do Sul, observing the manner in which they construct a determined image of themselves. Initially I try to situate the reader with respect to the institution and the construction of such interviews. Afterwards, I try to analyze the feminine memoranda that people this study through the three roles that they occupy within the institution, which recur in their talk: a married person, a mother and a widow. I attempt to perceive the images constructed through such speech, analyzing the version of themselves that they wish to prevail.

Keywords: Hansen's disease; memory; subjectivation.

\footnotetext{
* Doutoranda em História na Universidade Federal do Rio Grande do Sul (PPG/UFRGS), bolsista Capes. Secretaria do Programa de Pós-Graduação em História, Instituto de Filosofia e Ciências Humanas (UFRGS), Av. Bento Gonçalves, 9500, Bloco 3, Prédio 43311, Sala 114, Bairro Agronomia. 91509-900 Porto Alegre - RS - Brasil. borgesviviane@hotmail.com.
} 
As rememorações que busco analisar se inserem numa tessitura nada comum. As senhoras que apresento ao leitor fazem parte de um pequeno grupo de pessoas que ainda hoje habitam o espaço que atendeu e segregou a lepra no Rio Grande do Sul. Refiro-me ao Hospital Colônia Itapuã, criado em 1940, em nome de uma política nacional de controle e prevenção da lepra implantada nas primeiras décadas do século XX no Brasil.

A internação somente deixou de ser compulsória no final da década de 1950, em razão do avanço no tratamento da doença e da diminuição da incidência desta no Rio Grande do Sul. Com isso, os pacientes finalmente poderiam retornar ao convívio social, retomando suas vidas em seus locais de origem. Não foi tão simples assim. Muitos retornaram à instituição, vítimas do preconceito, carregando um estigma que impossibilitava a reintegração social. Conforme Serres: ${ }^{1}$

A dificuldade da reintegração social foi algo que acompanhou os doentes, não apenas quando a doença deixava alguma seqüela física, mas quando - como no caso da maioria dos entrevistados pela pesquisa - a reintegração passava por omitir (ou mentir?) o passado, principalmente quando vivido no Leprosário. Como preencher a lacuna dos anos em que se viveu fora da sociedade? A solução encontrada por muitos foi fixar residência em locais distantes de suas antigas comunidades.

Segundo Goffman, ${ }^{2}$ um estigma pode ser definido como um sinal exterior que desqualifica o sujeito impossibilitando a aceitação social. Esse atributo depreciativo comprometeria a identidade social do sujeito estigmatizado. $\mathrm{O}$ autor classifica os estigmas em três tipos: 1) aqueles relacionados ao corpo, envolvendo deformidades físicas; 2) vinculados às culpas individuais, tais como os vícios; 3 ) relacionados a grupos, como os de raça e religião. $\mathrm{O}$ estigma carregado pelo leproso é perpassado por tais atributos depreciativos, comprometendo a identidade social do indivíduo doente, impossibilitando o retorno ao convívio social. Desta forma, a passagem pela instituição acabava estigmatizando o doente, considerado pela sociedade 'sadia' um perigo social a ser segregado.

Assim, muitos nem sequer ousaram sair da instituição. O Hospital se tornara seu local de moradia, haviam encontrado na instituição "um lugar para si". ${ }^{3}$ Contudo, o número de internados diminuiu, passando de 700 para 340 em 1960, tornando-se necessário repensar sobre as finalidades daquele espaço agora ocioso. Assim, em 1972 a instituição passou também a abrigar pa- 
cientes portadores de sofrimento psíquico provenientes do Hospital Psiquiátrico São Pedro. ${ }^{4}$

Cerca de 180 pacientes-moradores ainda habitam o velho Hospital. Foi a preocupação de preservar a história desse espaço que motivou a criação do Centro de Documentação e Pesquisa (Cedope), em 2000. Sob esta perspectiva foram realizadas 26 entrevistas com homens e mulheres da chamada UIH (Unidade de Internamento Hanseniano), com pacientes da UIP (Unidade de Internamento Psiquiátrico), com as irmãs franciscanas e com médicos que atuaram no Hospital. ${ }^{5}$

A metodologia empregada para a realização de tais depoimentos foi a história oral de vida. Esse método caracteriza-se principalmente pela subjetividade, permitindo que "ao longo da narrativa da trajetória de vida" os temas relevantes para a pesquisa sejam aprofundados. ${ }^{6} \mathrm{O}$ objetivo era apreender as impressões dos internados a respeito do Hospital.

Neste estudo, não pretendo tentar ler nas entrelinhas de tais depoimentos, buscando um 'não dito' oculto em suas falas, mas sim analisar exatamente aquilo que foi pronunciado, empreendendo uma análise enunciativa. Sob tal perspectiva, tem-se uma análise histórica que se refere "às coisas ditas, não pergunta o que escondem, o que nelas estava dito ou não dito que involuntariamente recobrem, a abundância de pensamentos, imagens ou fantasmas que as habitam".7

Pretendo inquirir a invenção de si empreendida por tais senhoras, a maneira como estas constituíram a si mesmas, pensando a respeito da "reflexão sobre os modos de vida, sobre as escolhas da existência, sobre o modo de regular sua conduta, de se fixar a si mesmo fins e meios". Tais técnicas de subjetivação carregam a um só tempo práticas de sujeição e de liberdade, as quais constituem os sujeitos, pois, conforme Foucault,

o sujeito se constitui através de práticas de sujeição, ou de maneira mais autônoma, através de práticas de liberação, de liberdade, como na Antiguidade - a partir, obviamente, de um certo número de regras, de estilos, de convenções que podemos encontrar no meio cultural. (Foucault, 2004, p.291)

Cercadas pelo meio institucional, as senhoras a que me refiro encontraram em si mesmas uma escapatória às sujeições. Voltaram-se a si mesmas, "como um porto abrigado das tempestades ou como uma cidadela protegida por suas muralhas". ${ }^{8}$ Neste sentido, suas falas procuram instituir existências regradas, as quais fizeram das normas asilares não um dever, mas uma opção. 
No processo de invenção de si tais senhoras procuram desenhar suas vidas conforme a instituição desejava, insistindo que esse foi um caminho escolhido e não imposto, produzindo e reativando para consigo e para com os outros as verdades as quais necessitavam. ${ }^{9}$

Conforme mencionado, neste artigo procuro problematizar as memórias de quatro senhoras da Unidade de Internamento Hanseniano (UIH). Para escolher tais personagens estabeleci alguns critérios: senhoras viúvas, com idade superior a 60 anos e período de internação superior a 50 anos. Fui incitada pelos temas recorrentes em suas falas, os detalhes sobre a maneira como conheceram seus maridos, a comoção e solidariedade com a questão dos filhos nascidos na Colônia, e as marcas deixadas pela viuvez. Nesse sentido, procuro perceber as imagens construídas a partir de tais narrativas, concentrando-me no que foi dito e na maneira como tais personagens instituíram a si mesmas.

Cabe mencionar que decidi analisar somente entrevistas que eu mesma tivesse realizado. Tal decisão deve-se unicamente às peculiaridades que envolvem o trabalho de história oral num ambiente como o do Hospital Colônia. Condenadas por uma política de saúde pública segregadora, as pacientes-moradoras que transitam por este estudo foram forçadas a fazer da instituição seu lar. Diante dessa realidade, as circunstâncias e os locais em que se realizavam algumas das entrevistas eram, em alguns casos, perturbadores e tristes. Lembro-me que em duas ocasiões realizei entrevistas na enfermaria; uma delas foi com uma senhora que havia perdido as duas pernas e que vivia na instituição havia mais de 60 anos, a quem chamarei de dona Clara. Para estudar essas existências condenadas pelo preconceito, creio que interessa ao pesquisador não apenas a fala, mas também um olhar, um sorriso, ou uma lágrima, enfim, as expressões narradas pelo corpo, as quais somente o entrevistador pode trazer à pesquisa.

Não pretendo definir sujeitos, fixando identidades, mas sim pensar um conjunto de posições subjetivas possíveis, simultâneas e emaranhadas, instituídas pela fala das entrevistadas. Sob esta perspectiva, passo agora a investigar as posições de sujeito ocupadas por dona Leonora, dona Clara, dona Iracema e dona Elba em três momentos de suas existências: o casamento, a maternidade e a viuvez. 


\section{OS CASAMENTOS}

A tessitura narrativa que constrói as memórias aqui analisadas percorre caminhos semelhantes, compondo rememorações cercadas pelas minúcias que povoam o cotidiano. Analisando a construção empreendida por tais senhoras procuro perceber a maneira como estas instituíram determinada versão para suas uniões amorosas, bem como as imagens criadas a partir de suas falas para definir suas experiências. Nesta perspectiva sigo a seguinte ordem cronológica por elas estabelecida: os namoros controlados, a escolha de "maridos trabalhadores" e a descrição das "festinhas" de casamento.

Conforme dona Leonora, ${ }^{10}$ havia uma série de "leis" regulando o espaço institucional, inclusive no que se referia aos namoros entre os internados, e salienta com resignação: "era assim, tinha que ser, mas era bom”. Segundo as entrevistadas, os diretores "faziam rondas" à noite pelos pavilhões para tentar flagrar algum casal desavisado. Contudo, as senhoras afirmam que, apesar dessa vigilância constante, os namoros escondidos insistiam em ocorrer: "namoravam, isso é verdade!".

Os poucos espaços de sociabilidade existentes na instituição favoreciam “as paqueras". No cinema, por exemplo, localizado no chamado Pavilhão de Diversões, embora fosse norma que homens sentassem de um lado e as mulheres de outro, nada impedia os flertes. Também o refeitório oferecia alguma possibilidade de contato. Foi esse o local escolhido pelo falecido marido de dona Clara ${ }^{11}$ para a "conversa" que resultaria em matrimônio:

um belo dia ele mandou um bilhetinho pra mim, mandou pelo amigo dele né, o bilhete. Dizendo de meio-dia ele vinha de lá almoçar aqui no refeitório, nós todos sempre ia comer no refeitório ... disse que se eu quisesse ele tinha vontade de conversar comigo, e quem sabe que nós (risos) ah ... fosse namorado, tava interessado em mim.

Muitos relacionamentos também começavam nos bailes que aconteciam freqüentemente na instituição. O namoro de dona Iracema, ${ }^{12}$ por exemplo, começou num desses eventos: "fomos num baile em agosto e lá já começamos a namorar, namoremo um pouco... um tempo e casemo".

Namorar nos pavilhões era proibido. De acordo com dona Clara, funcionava da seguinte forma: "no pavilhão era proibido, ele podia ficar só até na calçada e lá chamava a moça no pavilhão, conversava algumas palavras e depois já tinha que ir embora, não muito tempo também, era assim”. 
Apesar de instituírem uma versão de si que procura mostrar uma total liberdade na escolha dos pretendentes, era o controle institucional que deveria aprovar ou não os matrimônios. Tal interferência não parece ter sido questionada pelas senhoras entrevistadas, ao contrário, compõe uma imagem de resignação, a instituição de um destino inevitável.

A “escolha” dos maridos parecia ser realizada conforme os desejos das irmãs franciscanas e dos médicos. Conforme dona Leonora, não havia discussões a esse respeito, pois "prá casar tinha que tirar ordem do médico, licença né e as irmãs também, se elas aceitavam tudo bem, e se não aceitavam, um prá cá outro prá lá ... a pessoa não casava, mas se dava igual né? Conversava e tudo, ia pro cinema lá junto, mas não casava”.

As irmãs franciscanas que cuidavam dos doentes impunham a união católica, só havendo uma saída para os noivos adeptos de outras religiões: a conversão. No casamento de dona Clara, por exemplo, ocorreu uma série de atritos, segundo ela "por causa da religião, nós não éramos católicos e as irmãs disseram: aqui ninguém casa fora da igreja, aqui tem que casar tudo na igreja”. Dona Elba ${ }^{13}$ conta que precisou tornar-se católica para poder se casar: "pra me casar foi aí que eu fiquei católica, aí eu me batizei, aí tudo essas coisa”.

A resignação à vontade das irmãs parece estar ligada ao forte respeito e gratidão que as enfermas nutrem em relação a elas. Mesmo havendo alguns atritos, principalmente entre aqueles pacientes que não eram católicos e que se viam obrigados à conversão para poderem se casar, a relação das entrevistadas com as irmãs é descrita com saudosismo. Cito alguns trechos das falas dessas senhoras a este respeito:

Foi a irmã Lúcia lá, ela tá em São Leopoldo, essa foi a última que foi embora daqui, essa era uma querida irmã, ai essa eu não me esqueço nunca dessa irmã, como era querida essa irmã pra mim e mais a morte do meu velhinho, falecido, como ela era boa pra mim. (Dona Clara)

Eram muito boa bah... sabe, diz que não sei é assim certo, foi um diretori que tirou elas daqui né, mas ela não queriam ir embora, não. (Dona Leonora)

Era que nem filho e elas eram as mãe nossa. (Dona Iracema)

É, é, eles eram, sabe as irmãs aqui foram muito boa né, como elas fizeram aqui, assim, foram boa pra nóis tudo, elas cuidavam muito de nóis assim. (Dona Elba)

A interferência das religiosas parecia ser encarada de forma natural pelas entrevistadas, contudo é necessário desnaturalizá-la, pensando nas razões des- 
se apreço sem limites. A obediência garantia a plena aceitação no meio em que viviam. Além disso, diante do abandono da família e da discriminação do meio social, o trabalho realizado pelas irmãs franciscanas parece ter sido muito valorizado pelas internadas. Nos discursos das velhas senhoras, as irmãs são descritas como "boas", como "mães" cuidando dos seus filhos, os pacientes. Tais fatores faziam que as palavras e os julgamentos das religiosas fossem considerados decisivos para a vida das entrevistadas, a ponto de definir com quem estas deveriam se casar.

A capilaridade do discurso das franciscanas parece ter se introjetado na imagem de si que tais senhoras desejam imprimir, como uma verdade instituída a ser seguida e mantida ainda hoje em suas falas. Nesse processo de reconstrução de si tais senhoras parecem ter encontrado em suas próprias trajetórias uma escapatória às sujeições, fazendo das normas institucionais suas próprias escolhas (Foucault, 2005, p.69).

Também os médicos interferiam nos relacionamentos dentro do Hospital, na tentativa de regular o cotidiano institucional, cumprindo a política de saúde pública da época. Neste sentido, tanto os casamentos quanto os filhos dos pacientes internados no Leprosário gaúcho estavam regulamentados através do Decreto no 7558 , de 11 de novembro de 1938. Conforme esse documento,

o casamento entre doentes de lepra internados só será realizado com assentimento da administração dos estabelecimentos, que atenderá, salvo casos especiais, à sua oportunidade em relação ao estado da evolução da doença e à capacidade de seção destinada à habitação dos casados. (Decreto no $7558,11.11 .1938$ )

De acordo com o referido Decreto, tal "licença” médica referia-se aos exames realizados nos doentes. Alguns tinham condições de receber alta e viver longe da instituição, mas preferiam ficar. Dona Clara, por exemplo, conta que logo no início de seu namoro foi chamada pelo médico que disse "tu não vai ficar mais muito tempo aqui eu vou te mandar embora, tu tá em bom estado!". Mas a velha senhora desejava permanecer no Hospital por dois motivos: para ficar junto de sua mãe, também paciente, e para casar-se com seu então namorado. Depois de advertida de seu "bom estado" e do desejo médico de conceder-lhe alta, foi chamada novamente para uma conversa a respeito de seu futuro marido. O médico salientou as qualidades do pretendente, o fato de ser ele "um homem trabalhador", parecendo desejar apressar o casório: 
"E você se interessa de casar?" Não sei doutor a récem que eu tô namorando ele, pode ser. "Não, ele é um homem muito boa pessoa, é um homem trabalhador, pobre mas ele é honesto e trabalhador, nunca se tem uma queixa dele", ele disse pra mim. Disse: "e faço gosto e vê se não demora muito, eu não quero muito namorisco aqui", diz ele.

A narrativa de si tecida por tais senhoras institui casamentos com homens "trabalhadores", com o devido consentimento religioso e médico. As entrevistadas parecem muito preocupadas em ressaltar tais elementos, procurando moldar casamentos realizados sob a bênção das irmãs e dos doutores, com maridos "bons" e "trabalhadores". Descrevê-los desta forma não é uma escolha aleatória e sim uma opção, uma maneira de instituir companheiros dignos de admiração e orgulho. A importância do matrimônio, a felicidade de encontrar um marido "trabalhador" e a realização de um casamento aprovado pela instituição são marcos biográficos que se repetem nas diferentes falas. Tais repetições desejam fixar determinados aspectos de suas vivências, sendo a escolha de um "companheiro" o elemento determinante para felicidade de tais senhoras.

Maridos trabalhadores e casamentos "bonitos" e "simples”. Os casamentos são instituídos como "festas simples", na maioria dos casos no diminutivo, "festinhas". Dona Clara se recorda de sua "festinha" e de sua noite de núpcias na "Chácara dos noivos": "da igreja saímos então caminhando até lá na chácara os noivos e a orquestra atrás de nós, era bonito até”.

As fotografias mostram casamentos simples e tradicionais. Noivas de branco, véu e grinalda. Aquelas que escolhiam outras opções que alterassem o tradicional figurino eram criticadas. Segundo dona Leonora "a noiva dele foi vestida de branco e as outras duas foram de cor-de-rosa, eu não achei bonito casar de cor-de-rosa, não, não, noiva tem que ser de branco".

No mesmo dia eram realizados vários casamentos. Conforme dona Leonora, no dia de sua cerimônia ocorreram outros casamentos: "Naquele dia foram realizados mais três casamentos". Dona Clara conta que havia muitas cerimônias de casamento: "Tinha ... bastantes moças casavam aqui, olha eu vi bastantes moças ... eu casei com outra ainda, outra casou de manhã às oito horas e nosso casamento parece que às nove era, nove e meia ... eu casei de manhã cedo, lembro de me aprontando, a noiva”.

A instituição permitia os casamentos entre os doentes com o objetivo de fixá-los naquele espaço, visto que a idéia inicial de esterilizar os pacientes acometidos pela lepra foi logo abandonada, pois, 
havia o temor de que os doentes esterilizados, na certeza da impossibilidade da procriação, se tornassem promíscuos, possibilitando o aumento da propagação de doenças venéreas. Não havia leis que os impedissem de casar, e do ponto de vista profilático, o casamento até era prática indicada, pois fixaria mais o doente nas colônias. (Serres, 2004, p.62)

As memórias dessas senhoras parecem descrever situações que acontecem a todo momento nos mais variados contextos sociais. Festas "simples" e "bonitas", namoros escondidos, bilhetinhos, noivas de branco, orquestras, igreja, tudo muito comum se não fosse pelo fato de serem relacionamentos regulados e incentivados por uma instituição que desejava fixar seus doentes, garantindo a ordem interna. Ao narrarem suas trajetórias tais senhoras traçam um caminho fixo e linear, instituindo uma unidade de sentido às suas existências, inventando a si próprias. Os casamentos são descritos como realidades à parte, numa tessitura quase uniforme, em que as histórias de vida se assemelham. Tal perspectiva cria "a ilusão de uma identidade específica, estável, coerente e sem contradições, que não é senão um biombo ou a máscara, ou ainda o papel oficial, de uma miríade de fragmentos estilhaçados”. ${ }^{14}$

Ouvindo seus relatos nos reportamos a uma realidade que se descola da instituição e da pretensa coerência que pretendem instituir a suas existências. Conforme veremos agora, a tessitura calma e uniforme de suas falas é abalada pelas memórias referentes aos filhos, frutos dessas uniões institucionais.

\section{MaternidADE}

O processo de subjetivação empreendido pelas entrevistadas institui vidas marcadas por casamentos aceitos pelo meio institucional onde viviam, com maridos trabalhadores. Essa auto-imagem elaborada pelas personagens é cercada pelo que Foucault chama de processo de subjetivação, produzindo modos de existência e estilos de vida. ${ }^{15}$

No desejo de constituir uma família, nada mais natural que tais senhoras desejassem a maternidade. Careli, ainda que referindo-se à concepção de virtude feminina no século XIX, parece bem de acordo com a perspectiva que parecia envolver o cotidiano institucional que cercava as entrevistadas: "a virtude feminina residia na existência do recato e do pudor, constituindo-se ambos em elementos fundamentais para o cumprimento da missão que fora investida por Deus, pela natureza e pela sociedade: a maternidade". ${ }^{16}$

Através dos relatos dessas senhoras é possível perceber que em sua cons- 
tituição de si enquanto mulheres virtuosas, ter filhos era quase uma obrigação, era isso que esperavam delas dentro do meio social em que viviam. Todavia, por muitos anos, ser mãe dentro do Hospital Colônia não era algo simples. Ter filhos envolvia questões de saúde pública que interferiram drasticamente na vida dessas mulheres.

Os filhos resultantes dos casamentos realizados no Hospital eram encaminhados ao Amparo Santa Cruz, construído também em 1940, no bairro Belém Velho, em Porto Alegre. As mães somente poderiam vê-los de longe, através da cerca que separava a "ala doente" da "ala sadia". Conforme o Decreto anteriormente citado,

os filhos de doente de lepra, logo após o nascimento, embora um só dos progenitores seja doente, serão separados e mantidos até à adolescência, quer em vigilância em domicilio, quer em preventórios especiais que, quando localizados na área do estabelecimento, ficarão anexos à zona de habitação das pessoas sãs, não podendo em caso algum ser nutridos no seio de uma ama nem amamentados pela própria mãe, se esta estiver doente de lepra.

A perspectiva de constituir uma família, de casar-se e ter filhos era assombrada pelo destino das crianças, tema delicado que ainda emociona as entrevistadas. Dona Leonora, após falar de sua trajetória dentro da instituição salienta que esse é o assunto que "tocou fundo o coração": "Ah, as crianças... agora chegou num ponto que tocou fundo o coração da gente. Quando a mulher ganhava nenê na enfermaria, o filho era arrancado dos braços da mãe e levado pro Amparo. Naquela época não podia ter criança aqui dentro, não deixavam, não era permitido ... Eu ia uma vez por mês lá visitar as minhas gurias.

A coerência presente nas falas que procuram instituir casamentos desejados e felizes choca-se com os sentimentos contraditórios que envolvem a questão da maternidade. Sobre este aspecto delicado, o sentimento de revolta é ressaltado por tais mulheres. Dona Leonora, por exemplo, afirma: "eu fico revoltada aí sabe o que, porque nóis ganhava as criança e já ia embora prá lá, só via quando nascia né, depois quando ficava boa a gente tinha ordem prá ir lá visitá eles né, mas ficá aqui não, não ficava com os pai”.

Contudo, mesmo sabendo que não poderiam ficar com as crianças, ser mãe parece ter sido um desejo de todas as entrevistadas. Destas, duas não tiveram filhos, dona Iracema e dona Clara. As razões para um casamento sem maternidade parecem perturbar essas velhas senhoras, trazendo à tona lem- 
branças desagradáveis. Na sua constituição de si dona Iracema parece tentar proteger seus dois maridos, frisando que não tiveram filhos, pois ela não podia engravidar, parecendo envergonhar-se por não ter sido mãe: “eu não prestava né ... eu não tinha filhos, por causa que meu marido era viúvo, né? Ele tinha filho e eu não tinha filho nenhum. Depois eu viuvei, casei novamente. E o outro também era viúvo tinha filho e eu não ganhei, então era eu que não prestava, né?".

Dona Clara também não teve filhos. Quando toquei nesse assunto, a frágil senhora parecia constrangida. Questionei se ela havia tido filhos, sua resposta foi: "Não, não, não, porque... depois ficou doente sabe, meu marido, ele... Não sei como é que se diz, que ele não era mais... pra... nada mais.... Seguiu-se um longo silêncio. Esperei, pois minha intenção era deixar que dona Clara falasse, procurando não interrompê-la. Então questionei, quase como uma constatação diante de suas palavras entrecortadas: "ele não conseguia mais ter filhos?". Constrangida, ela respondeu:

Não, não, não, nenhum filho. O doutor me chamou um dia, eu me assustei ... eu pensei "mas o que será que esse doutor quer comigo? Eu não consultei nem nada". Ele queria me explicar o causo dele, né? Então ele disse: "é Carolina tu queria muito um filhinho, mas não vai ter filho não, não vai ter filho e pouco tempo tu vai ter teu marido", diz ele ... Eu era casada quarenta e seis ano minha querida e só quinze anos eu tinha meu marido como mulher.

Conforme cabia à administração hospitalar, dona Clara foi alertada sobre seu destino: jamais teria filhos e por pouco tempo teria relações sexuais com seu marido. A velha senhora institui sua imagem de esposa resignada, salientando que permaneceu ao lado de seu marido por 46 anos. Mas não se coloca como vítima, elencando as qualidades do esposo, sorrindo e afirmando: "mas como ele era bom pra mim! Mas, sempre... sempre, assim mesmo nós vivia, como dois inocentes, né? na mesma cama dormindo, brincando, mas fora de coisa". Então questionei abertamente: "Não podiam ter relações?". Sua resposta foi quase um sussurro: "Não, não, não".

Segundo Julian Pitt-Rivers, tanto a honra quanto a vergonha são elementos constitutivos da virtude feminina (citado em Deleuze, 2006, p.137). Tais elementos podem ser percebidos nas falas dessas senhoras, mulheres que desenham suas rememorações procurando ressaltar sua honra e sua lealdade aos maridos, demonstrando vergonha diante da impossibilidade de serem mães, independentemente das razões. 
O destino das crianças nascidas dentro da instituição parece ainda sensibilizar as quatro entrevistadas. Mesmo sem ter filhos dona Iracema conta que se desesperava com os episódios que se seguiam aos nascimentos dentro da instituição:

eu ficava desesperada, porque quando nasciam as criança ah ... e mãe via aquela hora que nasceu, depois levavam lá prá fora, aí batizavam ali no corredor do lado de lá né, naquelas peças que tem ali da enfermaria ... as crianças batizada ali e depois então prá vim amostravam prá mãe e levaram lá pro amparo Santa Cruz ... Quando vinha aqui, um ficava pro lado de lá da cerca e outro pro lado de cá, não tocava nos filho.

O parto, término de uma longa espera, momento de realização para grande parte das mulheres, tornava-se o início de uma nova dor para essas senhoras. Relatos de crianças "arrancadas", "levadas", contra a vontade das mães se repetem na teia discursiva por elas criada. O sentimento de indignação parece aproximar essas mulheres, mesmo aquelas que não tiveram filhos compartilham da mesma dor, se solidarizam. Esses marcos biográficos constituem verdades instituídas, formando uma rede de memórias traumáticas que garante uma solidariedade velada entre essas senhoras, marcadas pelo mesmo destino.

A ausência de contato físico é também ressaltada pelas entrevistadas, marcando o relacionamento entre pais e filhos. Dona Leonora, por exemplo, parece tentar resumir em poucas palavras a seqüência dos fatos que se seguiam ao nascimento das crianças nascidas no Hospital: "só ganhava eles, olhava, lavava, arrumavam e já enrolavam e levavam prá lá”. "Nós não tocava nos filhos", ressalta dona Iracema.

Embora o internamento tenha deixado de ser compulsório no final da década de 1950, somente em 1987 os filhos dos pacientes receberam permissão para permanecer na instituição junto com seus pais. ${ }^{17}$ Contudo, nem todas as mães concordaram com essa nova decisão. Dona Leonora, por exemplo, conta que estava na reunião em que tal notícia foi dada, e descreve sua reação:

Eu levantei em pé e disse assim: “não, a senhora vai me desculpá!”. Eu disse: "os meu não vêem prá cá morá aqui, porque quando eles nasceram não deixaram ficar com nós, né? mandaram prá lá e agora que tão grande! Que pode se 
fazer? que pode?" O serviço, trabalharem, prá viver ... aprender... que difícil! Que vão aprender aqui? ... os meu não!

As senhoras entrevistadas parecem surpresas com os poucos pais que demonstraram felicidade com o retorno dos filhos ao Hospital. Segundo dona Leonora, por exemplo, "teve muitos pai que ficaram facero, tão aí às vez ó sem fazer nada, só nas costa dos pai se enfiando né, não ... eu disse eu não quero, os meu não".

A instituição realmente não oferecia nenhum tipo de beneficio a esses jovens, nem mesmo uma escola regulamentada. Tal fato é alegado como um dos motivos pelos quais as entrevistadas não desejavam a permanência dos filhos na instituição, sendo essa a única maneira de lhes garantir "um futuro melhor".

Nas imagens instituídas pelas falas das entrevistadas querer bem aos filhos significava mantê-los longe do Hospital Colônia, e, conseqüentemente, longe delas mesmas. Na tentativa de legitimar suas rememorações, elas citam exemplos daqueles que voltaram e se tornaram pessoas "revoltadas". Conforme um estudo de caso realizado pelo Serviço Social da instituição em 1983, havia casos de filhos que tinham medo de serem contagiados, passando a agir com preconceito em relação aos pais, com atitudes de "repulsa" e "nojo". Segundo dona Iracema, todos que voltaram hoje são pessoas "revoltadas", pois, "não tiveram carinho de mãe, né? Não tem carinho de ninguém, só dos estranhos e olhe lá! Não é carinho que nem de uma mãe, né?”.

As imagens de si instituídas por tais senhoras são construídas por enunciados atravessados pelo cotidiano institucional. A reverberação dessa função enunciativa marcou a maneira como elas viam a si mesmas e suas percepções de si. O casamento, estimulado pela instituição, parecia trazer consigo, como ordem natural, o desejo de ser mãe. Contudo, a vida dentro do Hospital colocava situações dramáticas, episódios que marcaram muitas existências. Mesmo aquelas que não conseguiram cumprir seu papel social de mãe, se solidarizam e parecem ter sofrido do mesmo modo com a separação das crianças. Assim, a imagem que parece se perpetuar através de suas falas é do cumprimento de um dever, uma tentativa de reproduzir aquilo que consideram como natural na sociedade que as havia segregado, sob os olhos atentos da instituição e seus limites.

Essas mães que viram seus filhos crescerem através da cerca que separava o mundo 'sadio' do mundo 'doente', ressaltam em suas narrativas de si um outro elemento constitutivo de sua memória biográfica: a viuvez. 


\section{VIUVEZ}

Conferindo um sentido a suas trajetórias, as falas das senhoras aqui investigadas parecem instituir aquilo que acreditavam ser seu papel social, ou seja, ser esposa e mãe. Nesta perspectiva, a morte de seus maridos é relembrada como um fator determinante, compondo imagens que marcam suas vidas e o próprio tempo dentro da instituição.

As quatro senhoras entrevistadas se casaram, algumas mais de uma vez, como dona Iracema e dona Elba. Dona Iracema conta que trabalhava na costura antes de casar e que retomou o oficio após a morte do primeiro marido: "depois ele faleceu, aí eu só costurava, costurava, costurava sempre, que eu tinha a minha máquina, tinha e tenho né. Eu costurava, costurava barbaridade prá fora”. Segundo ela, o trabalho a mantinha ocupada, preenchendo o vazio deixado pela ausência do companheiro. O mesmo se repetiu quando enviuvou pela segunda vez; costurou tanto que chegou a preocupar os médicos:

Aí depois que eu fiquei viúva novamente, aí eu só costurava. Aí o dotor ... foi, que era médico que eu me tratava aqui. Eu disse assim, chamaram ali ... e disseram olha vocês dêem uma ocupação prá Iracema, ela disse não, ela já tem ocupação bastante, ela costura barbaridade, sempre tá costurando, amanhece e anoitece costurando e ele disse isso não é ocupação prá ela, tem que ser alguma coisa que ela tenha movimento.

O enredo biográfico desenhado por Iracema ressignifica a perda dos maridos, mostrando que seu esconderijo foi o trabalho, que a mantinha ocupada para não se lembrar da morte dos companheiros e da solidão que afirma sentir.

Conforme exposto anteriormente, alguns internados conseguiram obter alta e sair da instituição em busca da reinserção. Foi esse o caso de dona Elba. Ela recebeu alta e regressou para sua cidade de origem junto com seu segundo marido, mas a doença do companheiro obrigou o retorno ao Hospital. Ela regressou e não mais saiu. Sua narrativa constitui a imagem de uma esposa leal que cumpriu seu dever permanecendo ao lado do esposo até a hora da morte. Dona Elba afirma que permanece na instituição para que seja enterrada junto aos seus falecidos maridos.

As entrevistadas salientam que estavam presentes quando o falecimento ocorreu. Parecem tentar recompor esse passado, citando detalhes a respeito das complicações causadas pela doença e das expressões de dor dos compa- 
nheiros convalescentes. Dona Elma, por exemplo, faz questão de descrever a doença que acometeu seus dois maridos:

eu tive, os dois maridos, cada um mais doente que o outro. Que dizê, eles andavam, caminhavam bem tudo, mas o segundo tinha bronquite crônica, a crônica, não é a asmática, é a crônica, acho que é pior que a asmática ... Quando dava aqueles acesso né, tudo. E o primeiro era ... não fim ele ficou muito doente, não morreu dos pulmão, dos pulmão não, ele morreu de insuficiência renal.

Dona Clara se entristece ao recordar os gritos de dor de seu falecido "velhinho" antes de morrer:

Ele morreu do coração, aquele brabo, braba coisa que dá no coração, não sei ... ele sofreu muito umas hora ... mais gritava, gritava assim ... torcia de dor até na hora morrer, "é do coração!" o doutor tinha me dito isto ... os últimos dias começou a dor mais forte né, mais forte, tava aqui já na enfermaria ... quando deu aquela dor forte ... ele não durou mais muito, pouco, pouco tempo.

Regressar à vida asilar por causa da saúde dos cônjuges e cuidá-los até a morte, são aspectos que imprimem à vida dessas senhoras características consideradas positivas pelo meio social em que viviam, tais como o companheirismo e a lealdade. Ressaltam ainda uma valorização dos princípios religiosos que envolvem o matrimônio, como, por exemplo, a idéia de uma união que se mantenha firme na "saúde e na doença", "até que a morte os separe", como determina a religião católica. Tal ordenação da existência é narrada de forma coerente, como a única possibilidade a ser seguida, "como um relato coerente de uma seqüência de acontecimentos com significado e direção". ${ }^{18}$ Assim, é necessário ponderar tais falas como construções de si na tentativa de imprimir determinada versão de si, instituindo a imagem de si que acreditam ser a ideal.

\section{CONSIDERAÇÕES FINAIS}

Objetivei analisar alguns aspectos que se repetem nas falas de quatro mulheres que passaram a maior parte de suas existências dentro de uma instituição asilar: o casamento, a maternidade e a viuvez. São essas as posições de sujeito por elas ocupadas, mulheres casadas, que tentaram constituir uma família em meio aos limites colocados pela instituição, que ficaram ao lado de seus 
maridos até a hora da morte. É dessa forma que instituem a si mesmas, é essa a imagem que desejaram imprimir.

As normas institucionais parecem ter sido a origem e o limite de suas existências. Em suas reconstruções de si, as entrevistadas voltaram-se para suas próprias trajetórias, encontrando nestas uma escapatória às normas e sujeições (Foucault, 2005, p.69). A capilaridade do discurso asilar se mescla às narrativas de si de tais senhoras, num emaranhado de falas no qual parece impossível separar suas vontades das determinações institucionais.

Portanto, o casamento, a maternidade e a viuvez são temas recorrentes que perpassam as diferentes falas femininas, que se repetem e se cruzam numa tentativa de instituir marcos biográficos. Tais falas instituem imagens, buscando uma "identidade específica, estável, coerente e sem contradições" (Levi, 2002, p.173). Essa máscara que parece tentar encobrir as incertezas e incoerências do cotidiano é fortalecida através do que Foucault chama de técnicas de subjetivação (Deleuze, 2006, p.142). Sob esta perspectiva, tais senhoras produziram modos de existência e estilos de vida que instituem existências regradas, senhoras que acreditam ter cumprido seu papel social, memórias de mulheres hansenianas.

\section{NOTAS}

${ }^{1}$ SERRES, Juliane. Nós não caminhamos sós: o Hospital Colônia Itapuã e o combate à lepra no Rio Grande do Sul (1920-1950). Dissertação (Mestrado em História) - Universidade do Vale do Rio dos Sinos (Unisinos), São Leopoldo, 2004. p.166.

${ }^{2}$ GOFFMAN, Erving. Estigma. Notas sobre a manipulação da identidade deteriorada. 4.ed. Rio de Janeiro: Guanabara Koogan, 1988. p.13-14.

${ }^{3}$ Yonissa Wadi trata do fato de alguns internados perceberem o Hospício como um "lugar para si”, a partir dos escritos de uma mulher internada no Hospício São Pedro, em Porto Alegre, entre 1909 e 1911. WADI, Yonissa. "Um lugar todo seu!?”: paradoxos do viver em uma instituição psiquiátrica. Revista Varia História, Belo Horizonte, n.32, 2004.

${ }^{4}$ Em minha dissertação de mestrado, estudei o cotidiano do Centro Agrícola de Reabilitação. BORGES, Viviane Trindade. Loucos (nem sempre) mansos da estância: controle e resistência no cotidiano do Centro Agrícola de Reabilitação (1972-1982). Dissertação (Mestrado em História) - Universidade Federal do Rio Grande do Sul (UFRGS), Porto Alegre, 2006.

${ }^{5}$ As entrevistas a que me refiro foram realizadas durante meu estágio no Centro de Documentação e Pesquisa do Hospital Colônia Itapuã (2000-2002). No presente artigo optei 
por conservar os trechos das entrevistas em sua forma original, permitindo que os erros do português coloquial transpareçam ao leitor. Acredito que devam ser mantidos, pois "expressam a musicalidade própria da fala do narrador". WEBER, Regina. Os operários e a colméia. Trabalho e etnicidade no sul do Brasil. Ijuí: Uniijuí, 2002.

${ }^{6}$ ALBERTI, Verena. Manual de história oral. Rio de Janeiro: Ed. FGV, 2004. p.38.

${ }^{7}$ FOUCAULT, Michel. Ditos e escritos V. Ética, sexualidade, política. São Paulo: Forense Universitária, 2004. p.124.

${ }^{8}$ FOUCAULT, Michel. História da sexualidade 3. O cuidado de si. São Paulo: Graal, 2005. p.69.

${ }^{9}$ DELGADO, Andréa. A autobiografia e a invenção de si. In: A invenção de Cora Coralina na batalha das memórias. Tese (Doutorado em História) - Unicamp, Campinas, 2003. p.259.

${ }^{10}$ Dona Leonora vive no Hospital há 63 anos.

${ }^{11}$ Dona Clara faleceu em 2003; viveu no Hospital Colônia por 63 anos.

${ }^{12}$ Dona Iracema vive há 51 anos no Hospital Colônia Itapuã.

${ }^{13}$ Dona Elba vive na instituição há 58 anos.

${ }^{14}$ LEVI, Giovanni. Usos da biografia. In: AMADO, J.; FERREIRA, M. de M. Usos e abusos da história oral. Rio de Janeiro: Ed. FGV, 2002. p.173.

${ }^{15}$ DELEUZE, Gilles. Conversações (1972-1990). São Paulo: Ed. 34. 2006. p.142.

${ }^{16}$ CARELI, Sandra. Maternidade x aborto: com a palavra a "opinião pública". História em Revista, Pelotas: UFPEL, 2006, p.136.

${ }^{17}$ BORGES, Viviane Trindade. Segregar para curar? A experiência do Hospital Colônia Itapuã. Boletim da saúde, Porto Alegre: Escola de Saúde Pública, 2000, p.145.

${ }^{18}$ BOURDIEU, Pierre. A ilusão biográfica. In: AMADO, J. e FERREIRA, M. de M. Usos e abusos da história oral. Rio de Janeiro: Ed. da Fundação Getulio Vargas, 2002.

Artigo recebido em novembro de 2007. Aprovado em dezembro de 2007. 